\title{
И.И. Сизова
}

Институт мировой литературы им. А.М. Горького РАН, Москва

\section{История текста драматической обработки легенды о царе Аггее Л.Н. Толстого}

Аннотация: В статье исследуется история текста драматической обработки Л.Н. Толстого старинной легенды о царе Аггее («Повесть о царе Аггее и како пострада гордостию») на основе трех известных рукописей произведения, хранящихся в Отделе рукописей Государственного музея Л.Н. Толстого в Москве (ф. I, оп. 1-3, рукописной фонд составляет 39 листов). Сопоставление материала автографа и двух его копий с дневниковыми свидетельствами автора о проблематике и образной системе «драматических сцен» про обнищавшего пана, а также анализ источников легенды, которыми воспользовался писатель, позволяют уточнить крайние хронологические пределы художественного истолкования Толстым темы наказанной гордости (1879-1880, 1886).

The paper studies the history of the text of the dramatic adaptation by L.N. Tolstoy of an old legend about the Tzar Haggai («The Tale of Tsar Haggai and How his Pride was hurt») on the basis of three well-known manuscripts of the dramatical work, which is kept in the Manuscript Department of the State Museum of Leo Tolstoy in Moscow (f. I, op. 1-3, handwritten consists of of 39 sheets). The comparison of the autograph material and its two copies with the author's evidences in his diaries about some problems and the figurative system of «dramatic scenes» describing the impoverished nobleman life, as well as the analysis of expanded sources of the legend, which were used by the writer, make it possible to define more precisely the extreme chronological limits of the artistic interpretation by Tolstoy of the punished pride theme (1879-1880, 1886).

Ключевые слова: история и критика текста, датирование рукописей, автограф, копия, этапы формирования замысла, композиция произведения, источники сюжета, дневники и записные книжки, эпистолярное наследие, текстологический и историко-литературный комментарий.

History and criticism of the text, dating a manuscript, autograph, copy, stages of concept formation, work composition, plot sources, diaries and notebooks, epistolary heritage, textual, historical and literary commentary.

УДК: 82.081; 82.09; 82-2

Контактная информация: Москва, ул. Поварская, 25а. ИМЛИ РАН, отдел русской классической литературы. Тел. (495) 6970194. E-mail: u_sizova@bk.ru.

Сказки, легенды и аллегории получили не только право «полного гражданства», но и «особенные привилегии» в русской литературе восьмидесятых годов XIX в. Эти жанровые виды составили «любимый род» для крупных писателейреалистов. Л.Н. Толстой перерабатывал легенды и сказки в цикле народных рассказов. М.Е. Салтыков-Щедрин (Н. Щедрин) выбрал сказку как наиболее подходящую форму для выражения своих мыслей. В.М. Гаршина привлекала та же художественная форма («То, чего не было», «Роза и жаба», «Сказание о гордом Аг- 
гее» и др.). В.Г. Короленко начал новую серию своих произведений аллегорическим «Сном Макара».

В драматической обработке легенды об Аггее Толстой обратился к распространенной на Востоке и Западе легенде, встречающейся в рукописных сборниках XVII и XVIII столетий. В русской литературе на протяжении XVII в. складывался круг переводных и оригинальных произведений, по-разному перерабатывающих сюжет о наказании гордого царя, но внутренне связанных друг с другом. Повесть о царе Газие появилась в 1640-е гг. Рассказ о гордом царе вошел в книгу религиозных сказаний «Небо Новое» украинского литературного и церковного деятеля И. Галятовского (около 1665 г.). «Повесть о искушении Бога, о царе некоем» написана С.В. Жюлевым в 1665 г. Со второй половины 1670-х гг. известен Приклад о гордом цесаре Иовениане из Римских деяний. «Повесть о царе Аггее, како пострада гордости ради» возникла на рубеже 1670-х - 1680-х гг., «Повесть о Димитрии Римском» - в начале XVIII в. [Ромодановская, 1985, с. 3].

Ко времени обращения Толстого к сюжету о наказании гордого царя появились научные описания и печатные версии легенды. П.М. Строев указал два рукописных сборника XVII в. из собрания И.Н. Царского со схожими ее вариациями [Рукописи славянские и российские, 1848, с. 496, 610]. Развернутое текстологическое описание предания предпринял А.Н. Пыпин в «Очерке литературной истории старинных повестей и сказок русских» (1857). Научные изыскания Строева и Пыпина были известны Толстому по трудам А.Н. Афанасьева.

Впервые два варианта легенды (книжный и народный) опубликовал целиком А.Н. Афанасьев в сборнике «Народные русские легенды» (1859). Повествование о царе Аггее, близкое по содержанию книжной версии у Афанасьева, напечатал М.Ф. Шугуров в девятом номере «Русского архива» (1865). Народную обработку легенды «Гордый царь» на украинском языке представил И.Я. Рудченко в «Народных южнорусских сказках» (вып. 2, Киев, 1870). Ее перевод на русском языке появился в «Вестнике Европы» (1871, № 1). Первый выпуск Римских деяний (Gesta Romanorum) с Прикладом о гордом цесаре Евиняне был издан в СанктПетербурге (1877-1878). А.Н. Веселовский привел еще один вариант легенды в «Разысканиях в области русского духовного стиха» (1881), идентичный версиям Афанасьева и Шугурова.

Толстой взял за основу своего драматического действа народный пересказ и книжный вариант истории Аггея по работам Афанасьева и Шугурова. Писатель не дал своему герою имя Аггей (так в «Гордом богаче» у Афанасьева); он назван паном (в девятой картине Фадеем), а жена его - пани. В устном варианте богопротивный поступок правителя сопровождается раскатами грома и молнией. Толстой ввел это изображение в свою пьесу. Видимо, в использовании внешних театральных эффектов (буря, гром, молния), что в общем Толстой считал недопустимым в драматических произведениях, он желал сохранить характер источника или придерживался «канона» народной драмы. Третья картина о встрече пана с разбойниками близка, хотя и не тождественна, описанию засады, которую устроили пану двенадцать разбойников в «Гордом богаче». В Повести о царе Аггее властелин только говорит торговым людям, что его «пограбили» разбойники, но описания ограбления нет.

В основных же сюжетных узлах пьесы, в ее образной системе Толстой следовал книжной версии на славянском языке. Писатель творчески освоил и сохранил последовательность композиционных частей источника: эпизода в церкви, сцен охоты и встречи с пастухами, написания письма жене, работы у крестьянина, знакомства с нищими, прихода с ними на царский двор, обеда с нищими в «особой палате», сцены покаяния, приведенной Афанасьевым в разночтениях списка легенды под строкой. В книжных вариантах сказания исток образов Ангела и мехоноши из восьмой картины. 
Обработку старинной легенды об Аггее в драматической форме Толстой не завершил. Было написано девять картин и вводная ремарка к десятой картине. Сохранилось три рукописи: автограф и две копии. Автограф не имеет заглавия и даты [оп. 1]. Первая копия (рукой С.А. Толстой и неизвестного без исправлений Толстого) тоже не датирована, но предварительно озаглавлена (не Толстым): «Пан. Сцены и картины» [оп. 2].

Вторая копия (рукой неизвестного с правкой Толстого) выполнена в двух тетрадях. На начальном листе первой тетради С.А. Толстая указала предположительное время создания произведения: «Из рукописей 1876-1880-х годов (?)», и написала заголовок: «Драматические сцены о пане, который обнищал» [оп. 3].

Между тем самое раннее из известных свидетельств самого Толстого о знакомстве с историей царя Аггея относится к январю - февралю 1873 г. Записные книжки Толстого за 1879-й и 1880 г. содержат заметки об источниках, проблематике и образной системе «драматических сцен», что позволяет датировать этап создания автографа этим временем.

Дата 1 марта 1886 г. поставлена С.А. Толстой на обложке второй тетради, куда переписывались пьесы о наказании гордого царя [л. 2-11] и «Первый винокур» [л. 12-22]. Полагаем, что в 1886 г. автограф «сцен» про Аггея был скопирован и автор приступил к их правке, но бросил начатое (изменена только первая картина). Хронологические пределы этой работы пришлись на период с февраля по начало апреля (до 5-го). Из неопубликованного письма П.И. Бирюкова к В.Г. Черткову от 4 февраля [ОР ГМТ] ${ }^{1}$ и воспоминаний И.М. Ивакина [Литературное наследство, 1961, с. 81] известно о чтении и переработке Толстым легенд А.Н. Афанасьева. В письме к актеру П.А. Денисенко от 19 февраля Толстой говорил о своем желании написать для народа в драматической форме. 6 апреля Чертков сообщил Толстому о завершении В.М. Гаршиным «Сказания о гордом Аггее».

Прямых свидетельств Толстого о работе над «сценами» о пане нет в его переписке, дневнике и записных книжках 1886 г. Ничего не говорится о произведении в обширной мемуарной литературе близких и современников писателя, о нем умалчивает также эпистолярное общение родственников Толстого означенного периода.

Автограф пьесы занимает семь листов, шесть из которых заполнены с обеих сторон. Текст пяти картин написан в линованной тетради небольшого формата [оп. 1, л. 1-4 об.]. На четвертом листе знак «Х» возле фразы: «Приходят два нищих, слепой и безрукий»- относится к третьей сцене четвертой картины; саму вставку обозначает тот же знак на лицевой стороне пятого листа. В работе над окончанием пятой картины, шестой и седьмой картинами Толстой использовал другую бумагу: нелинованные листы большого формата [л. 6-6 об.]. На такой же бумаге заново написан текст пятой и шестой картин, создана девятая и зачин десятой картин [л. 5-5 об., 7].

Завязка действия пьесы в первой сцене (картине) сложилась сразу: у дверей церкви слуги с носилками дожидаются пана и его жену. Трое слуг обсуждают «удивительное» событие - их господин посещает церковь впервые за двадцать лет. Затем Толстой разделил текст на три части: в первую вошел разговор трех слуг, во вторую - кощунственный поступок пана в церкви, в третью - беседа пана с народом на ступенях храма.

Ранний вариант второй картины, где тема охоты правителя (преследование им оленя) является первой сценой, а во второй сцене едва лишь намечен мотив «чудесного» исчезновения пана, писатель вычеркнул. Тема наказания за кощунство стала центром нового варианта. Красноречивое исчезновение пана в первой

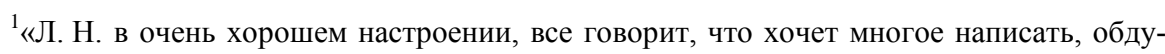
мывает Будду, читает легенды Афанасьева, говорит, что нашел там много превосходных тем». 
сцене отодвинуло на второй план описание его охоты во второй сцене [л. 1об.]. Тема наказания продолжена ниже: автор ввел в действие третьего охотника и вместе с этим важный сюжетный поворот. В события вмешалось «провидение». Третий охотник сообщает, что пан не пропал, а уехал домой.

Третья картина также писалась в несколько этапов. Сначала единый текст связывал содержание второй и первой сцен, без их цифрового разделения. Картина открывалась ремаркой: «Темный лес, сидят разбойники у костра» [л. 2 об.] и заканчивалась репликой пана, негодовавшего на оставивших его охотников: «Погоди, я вам размочу спины-то. Аааааа! (Уходит)» [л. 2]. Позднее появилось название части действия «Картина 3-я» и изменился порядок сцен. Первая сцена особо оттенила события, связанные с образом пана, показала начало его скитаний, осуществление «возмездия» провидения. Беседа разбойников в лесу стала менее значимой и переместилась во вторую сцену, которую теперь открыла ремарка: «Приходят разбойники с оружием, мешками и располагаются и разводят огонь» [л. 2].

Встречу разбойников и пана, с которым уже произошла «чудесная» метаморфоза (он лишен привычных атрибутов власти), Толстой планировал изобразить в четвертой картине, но передумал. Варианты начала: «Картина 4-я. [Пан.] [Те же и пан]»- заменены другим зачином, логично завершающим третью картину: «Сцена 3-я» [л. 3. об.]. События этой сцены предварили «мытарства» пана, наметили его первое «испытание»: разбойники избивают бывшего правителя и привязывают его к дереву.

Далее Толстой последовательно создал четыре картины, с четвертой по седьмую. Центр четвертой картины, состоящей из двух сцен, - второе «испытание» пана: пастухи отвязывают его от дерева, но не признают в нем своего господина. Писатель предполагал показать в третьей сцене знакомство и общение пана со слепым и безруким нищими (третье «испытание» пана), но перенес эту сюжетную линию в пятую картину.

Шестая картина описывала возвращение униженного правителя в его дом. Непривычна его взору нарядная дворня на господском дворе, танцы людей и их игра на балалайках. Впервые в репликах кучера и дворовой девушки прорисован облик Ангела, взявшего на себя «образ» пана: «Совсем другой с охоты приехал. Добрый, ласковый стал. <..> Лицо все то же, как и был пан, а только светлый стал, как ангел небесный» [л. 6]. Толстой подчеркнул, что и дома «мытарства» настоящего пана не заканчиваются, ведь нравственного перерождения в нем так и не происходит.

Седьмая картина очерчивала развязку пьесы (тема покаяния грешника) и изображала трапезу нищих в господских палатах, за которой им прислуживала пани. Пан признается жене: «Я [согре<шил>] ошибся, я неправду сказал» [л. 6 об.], - но на данном этапе развития характера покаяние героя выглядело преждевременным и неправдоподобным. Диалог пана и Ангела, еще один подступ к теме покаяния, оборвал действие. «Скажи мне, кто ты и зачем ты взял на себя образ мой?»- с недоумением вопрошает пан Ангела [л. 7].

В произведении пока еще недоставало важного звена. Не было самого главного, с точки зрения писателя, «испытания» пана - «общения» «господина» с крестьянином-земледельцем. Поэтому Толстой вернулся к пятой картине (встреча пана с нищими) и создал три самостоятельных фрагмента: картину пятую, картину без названия и шестую. В пятой картине пан встречается с мужиками; старик не верит тому, что перед ним настоящий пан. Но мужики сжалились над «молодцом» и отвезли его письмо к жене в деревню. Картина без названия сообщала о том, что и на господском дворе никто не поверил бывшему правителю. Шестая картина, в которой автор забыл поставить обозначение первой сцены, показывала новое «испытание» пана - мужицким трудом. 
Затем была перестроена композиция пьесы. Пятая картина стала третьей сценой четвертой картины и завершила на событийном уровне тему освобождения пана. В первой сцене он привязан к дереву, во второй сцене его освободили пастухи, в появившейся третьей сцене ему помогли мужики, позволившие написать жене. Картина без названия стала пятой, заострив еще один «удар» провидения: от пана отказалась жена, не признав в нем своего мужа. Картина пятая, повествовавшая о встрече пана с нищими, стала седьмой, прежний текст об обеде нищих в господских палатах писатель вычеркнул. Наконец, картина шестая, раскрывающая «испытания» пана на собственном дворе, куда он приходит вместе с нищими, стала восьмой.

Окончив переделку строя пьесы, Толстой написал девятую картину, далее начал, но оборвал картину десятую. В девятой картине писатель вновь вернулся к развязке произведения - теме покаяния - и впервые дал имя главному герою (Фадей). Ранее, в седьмой картине, пан сокрушался о своем грехе перед женой. Теперь «волшебные» образы усилили воздействие пьесы на читателя и зрителя. Пан обедает в царской палате уже не с нищими, а один. В момент горестного душевного опустошения героя, смирившегося с тем, что ему, видимо, суждено погибнуть в нужде, появился свет. Голос из света учит сильного, богатого и гордого правителя тому, что и богатый может обнищать. После покаяния Фадея Голос возвращает ему власть.

В картине десятой должно было быть показано правление «перерожденного» властелина. Написана только вводная ремарка: за большим великолепным столом сидят нищие, им служат пан с женой. На этом работа Толстого над пьесой приостановилась.

Первые две картины и начало третьей были скопированы в тетрадь, на обложке которой напечатано: «Магазин Аванцо. Москва. Кузнецкий мост» [оп. 2]. Из четырнадцати листов тетради заполнены три, два - с обеих сторон. Текст первой картины, до того момента, как пан выхватывает из рук дьякона Евангелие: «Как крикнет пан - Врешь, давай...» [л. 1-1об.], - скопирован С.А. Толстой. Продолжение первой, вторая и начало третьей картины, от слов: «...сюда книгу. Ухватил книгу» - до оборванной на середине фразы: «И леса то эти...» [л. 1 об.-3], переписаны неизвестным лицом. Рукопись не содержит правки автора. Копирование исказило текст пьесы. С.А. Толстая не заметила в автографе обозначение второй сцены первой картины, в реплике дворового человека объединила ранний и окончательный варианты. Второй копиист дословно следовал автографу и не расслаивал текст. Поэтому ранний вариант второй картины, который не следовало дублировать, сначала был переписан и только позднее вычеркнут. Аналогичная оплошность была допущена в ряде мест третьей картины. Встречаются примеры пропусков слов и целых фраз, ошибки прочтения; выпало обозначение первой сцены третьей картины. Приведем наиболее характерные подтверждения, принимающие иногда оттенок курьеза:

типы ошибок переписки
неверное расслоение
текста
изменение грамматиче-
ских форм
объединение двух пред-
ложений в одно
(С.А. Толстая)
ошибки прочтения, при-
ведшие к искажению
смысла
(копиист)

автограф

«Вошел в церковь в середине службы в шапке, стал посередине, глядит по сторонам. [Поглядел, поглядел, стал слушать.]» [оп. 1, л. 1].

«Как же я обнищаю, когда у меня 100 деревень и вся мне округа подвластна» [оп. 1 , л. 1 об.].

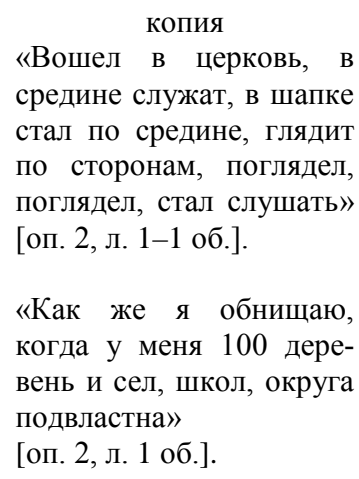
средине служат, в шапке стал по средине, глядит по сторонам, поглядел, поглядел, стал слушать» [оп. 2, л. 1-1 об.].

«Как же я обнищаю, когда у меня 100 деревень и сел, школ, округа подвластна» [оп. 2, л. 1 об.]. 


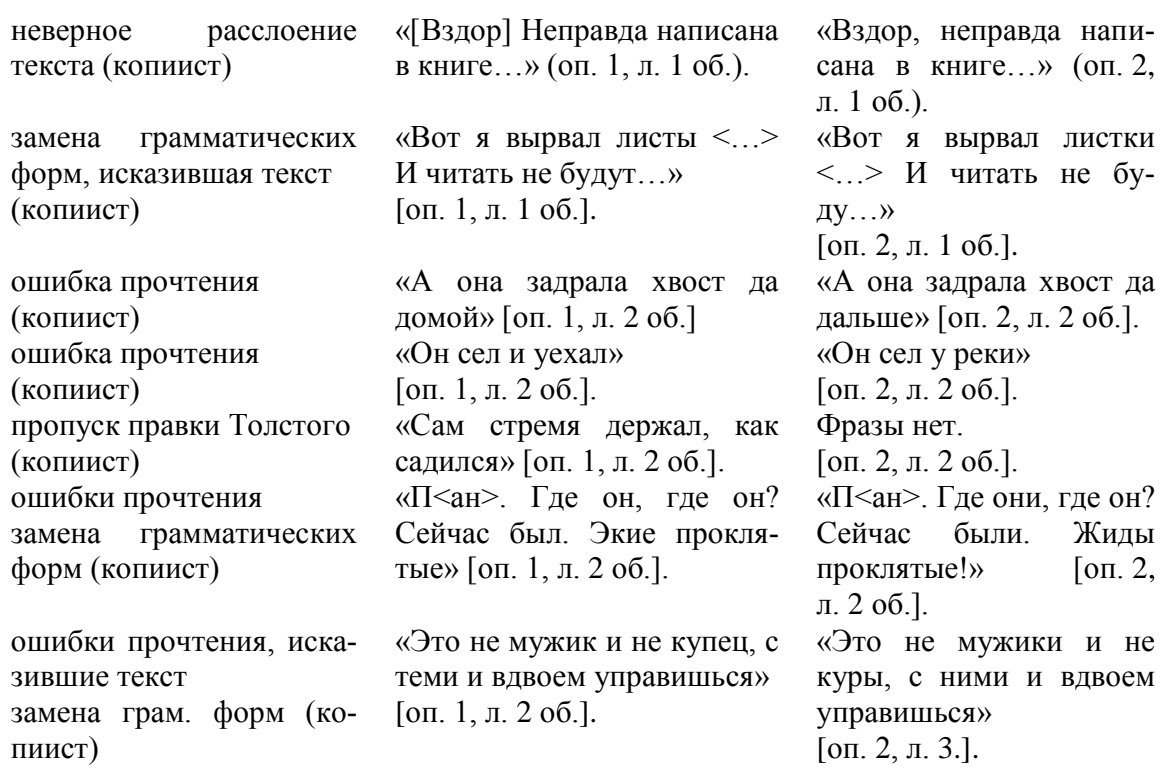

Вторая копия [рук. 3] находится в двух нелинованных тетрадях небольшого формата (двадцать девять листов); к работе был привлечен новый переписчик, личность которого не установлена. Пьеса готовилась для последующей ее правки писателем, поэтому между строками оставлено большое расстояние (2 см). Для достижения смысловой завершенности отдельные фрагменты дополнялись по контексту словами, которых нет в автографе, например, «1-й, 2-й и 3-й <слуги>» и т. п. - [л. 2], раскрывались авторские сокращения [л. 6 и др.], что воспроизводилось при всех публикациях пьесы. Переписчик учел правку Толстого третьей картины, но не разобрался в сложной композиционной перестройке произведения, проведенной художником в автографе, и включил вычеркнутую Толстым седьмую картину.

Рукопись изобилует многочисленными ошибками, допущенными при переписывании. Появились новые фразы. Например, «Занавес опускается» - вместо: «Занавес» [л. 3] или: «Нищий пан» - вместо: «Пан» [л. 10 об.-11*]. Нет обозначений третьей сцены второй картины [л. 14 об.] и второй сцены пятой картины, ошибочно названной в копии четвертой [л. 18]. Некоторые слова и предложения выпущены, непонятые в автографе фразы отмечены многоточием. Критическая сверка автографа и второй копии выявила примеры замены грамматических форм, в том числе синонимических замещений, «улучшения» стиля Толстого, неверного прочтения руки писателя и сокращения слов.

Толстой просмотрел вторую копию, но поправил только первую картину. Появилась предыстория кощунственного поступка властелина (разговор с женой о Писании). Было принято решение убрать полонизмы одного из источников пьесы («Гордый богач» у А.Н. Афанасьева), поэтому в названиях действующих лиц пана и пани сменили царь с царицей. В авторском истолковании образа главного героя наступил перелом: в реплике второго слуги заложена возможность покаяния правителя: «Дело из-за спора вышло; а кто знает, может, и покается» [оп. 3, л. 1]. На этом работа Толстого над «драматическими сценами» об обнищавшем гордеце остановилась.

Факт знакомства Толстого с легендой по научным трудам Шугурова и Афанасьева отражен в записных книжках писателя, что позволяет уточнить время создания «драматических сцен» о пане. В январе - феврале 1873 г. были сделаны

*'Вторая тетрадь, содержащая автограф пьесы «Первый винокур». 
заметки, свидетельствующие о художественном переосмыслении Толстым истории царя Аггея в жанре народного театра: «В Русск<ом $>$ Apx $<$ иве >. О царе Аггее». Рядом - нарицательное название народного театра по имени одного из его главных действующих лиц: «Петрушка Уксусо<в>» [Толстой, 1952, с. 97-98].

Развернутые замечания и рассуждения об источниках, образной системе и проблематике произведения появляются в записных книжках Толстого в 1879-м и в 1880 г. Эти эскизы неразрывно связывают религиозно-философские искания Толстого с вопросами народной литературы. Увлечение писателя народной темой заметно возросло после его знакомства с олонецким сказителем былин В.П. Шевелевым (Щеголенком), посетившим Ясную Поляну в июле 1879 г. Со слов Щеголенка Толстой записал легенды и рассказы, послужившие материалом для его художественного творчества («Чем люди живы», Два старика», «Молитва», «Три старца» и др.).

Вероятно, после отъезда Щеголенка из Ясной Поляны Толстой-художник поставил перед собой следующую творческую задачу: «Легенды Афанасьева и еще, какие есть. Странники и др. Тихонравова» [Толстой, 1952, с. 252]. Эта запись вновь скрепляет замысел о наказании гордого правителя с интересом Толстого к народной драме. Из работ историка русской литературы Н.С. Тихонравова внимание писателя могла привлечь не только рецензия ученого на сборник П.А. Бессонова «Калеки перехожие», но и его исследования по истории русского театра XVII-го и XVIII в.

Круг тем и образов «драматических сцен» про обнищавшего царя определенно сложился в записной книжке к августу 1879 г. Некоторые заметки дословно совпадают с текстом драмы. Ветхозаветный перифраз «С сильным не борись, с богатым не судись» преломлен в реплике одного из разбойников [Толстой, 1952, c. 240]. Разработка тем нищенства и милостыни в картине пятой опиралась на иную запись: «Милостыню примите, Христа ради» [Толстой, 1952, с. 243]. Здесь же текстовые параллели к истолкованию в пьесе образа пана: «А не Божья воля, не мог бы на царство сесть»; «Мехоноша»; «Путь потерял. Бог напомнил» [Толстой, 1952, с. 243-244].

В это время Толстой находился под сильным впечатлением от «Книги притчей Соломоновых», созвучие с которой прослеживается в основных положениях и тематике «сцен»: «Господь гордым противится, смиренным дает благодать»; «Нищета мужа смиряет»; «Строптивый гордец собирает огонь в устах», «Милуяй нищего взаим дает Богу» [Толстой, 1952, с. 245-246]. В письме от 30.. 31 августа Толстой рекомендовал А.А. Фету прочесть «Книгу притчей Соломоновых», «Экклезиаст» и «Книгу премудрости Соломоновой»: «...Я на днях прочел в первый раз и продолжаю читать и ахать от радости» [Толстой, 1953, с. 497]. Это письмо Толстого позволяет датировать предварительные наброски в его записной книжке августом 1879 г. и объясняет намерение Толстого дать евангельскую цитату в пьесе на славянском языке, так как переводы Библии на русский и английский языки, с его точки зрения, оказались «дурны».

Художественный поиск писателя в 1880 г. (после 7 июня) связал в один узел разработку центральной темы о духовном перерождении грешника, создание образной системы, выбор сюжетообразующей цитаты для «драматических сцен» с религиозно-философскими эскизами, из которых впоследствии выросли «Исповедь» и «Соединение и перевод четырех Евангелий». Осмысление Толстым в записной книжке Евангелия от Луки [заповеди блаженства из Нагорной проповеди - Толстой, 1952, с. 323, 331, 484 и др.] обусловило оригинальный выбор писателем сюжетообразующей цитаты: в основу всех известных к тому времени источников легенды об Аггее была положена Псалтирь.

Черновые варианты автографа пьесы дают представление о том, с каким трудом давалось Толстому художественное истолкование нравственного перерождения пана; неудачные, по мысли автора, подступы к этой теме не раз обрывали ра- 
боту над произведением. На страницах записной книжки Толстой рассуждал о роли провидения в судьбе человека, принимая вероятность постепенного духовного возрождения для каждой «потерявшей» правильный путь души: «Первый будет последним. <..> Переродиться духом. - Не вдруг возможно». Писатель оперировал греческим словом «метаноиа», переводимым двояко: как «покаяние» и как «изменение образа мыслей» [Толстой, 1952, с. 323].

С формированием в «сценах» фантастических образов, на том его этапе, когда было принято решение заменить образ Ангела образом Голоса, соотносима другая запись: «Глас не $<c>$ небеси, человеч<еский $>$. Вопиющий другое. Так мож<но> прямо в сердце. То и сделал» [Толстой, 1952, с. 324].

После 6 сентября 1880 г. Толстой внес в записную книжку краткую заметку, своего рода план к дальнейшему действию, содержательно близкий событиям начатой десятой картины, на которой работа над «сценами» прекратилась: «Угощение нищих» [Толстой, 1952, с. 306].

В середине восьмидесятых годов легенду о гордом правителе обрабатывал для «Посредника» В.М. Гаршин ${ }^{1}$. В «Сказании о гордом Аггее» с подзаголовком «Пересказ старинной легенды» Гаршин отклонился от традиционного сюжета и ввел добровольный отказ Аггея-Алексея от власти. В то же время художественное истолкование Гаршиным темы наказанной гордости в аллегорической форме, его желание опубликовать свое произведение в «Посреднике», обсуждение «Сказания...» в кругу единомышленников Толстого (чтение корректурных гранок) свидетельствовали об очевидном влиянии Толстого на его молодого современника. Гаршин вспоминал, что ему «радостно» говорили в «Посреднике»: «У вас более по-толстовски, чем у Толстого», и только тогда узнал, что Толстой тоже работал над легендой [Порудонимский, 1962, с. 278].

Рассказ Гаршина был напечатан в апрельской книге «Русской мысли» за 1886 г. 6 апреля Чертков сообщил об этом Толстому, что, возможно, и остановило работу писателя над пьесой.

\section{Литература}

Литературное наследство. Т. 69. М., 1961. Кн. ІІ.

Порудонимский Вл. Гаршин. М., 1962.

Ромодановская Е.К. Повести о гордом царе в рукописной традиции XVIIXVIII веков. Новосибирск, 1985.

Рукописи славянские и российские, принадлежащие почетному гражданину и археографической комиссии корреспонденту Ивану Никитичу Царскому. Разобраны и описаны Павлом Строевым. М., 1848. Оп. 1-3.

Толстой Л.Н. Драматическая обработка легенды об Аггее // ОР ГМТ. Ф. І.

Толстой Л.Н. Полное собрание сочинений: в 90 т. (Юбилейное издание). М.; Л.; 1928-1958. Т. 48-49. М.; Л., 1952. Т. 62. М.; Л., 1953.

\footnotetext{
${ }^{1}$ Из-за цензурных условий «Сказание о гордом Аггее» Гаршина было опубликовано в «Посреднике» только в 1900 г.
} 